\title{
Antenatal follow-up, anesthesia management and perinatal outcomes in pregnancy with renal transplant
}

\section{Renal transplanth gebelerin antenatal takibi, anestezi yönetimi ve perinatal sonuçları}

\author{
(D) Ezgi Turgut ${ }^{1}$, (1) Gözde İnan ${ }^{2}$, (1) Dudu Berrin Günaydın² ${ }^{2}$, (1) Beyza Büyükgebiz ${ }^{2}$, (D Sibel Koncal, \\ (1) Deniz Karçaaltıncaba ${ }^{1}$, (1) Merih Bayram¹ \\ ${ }^{1}$ Gazi University Faculty of Medicine, Department of Obstetrics and Gynecology, Ankara, Turkey \\ ${ }^{2}$ Gazi University Faculty of Medicine, Department of Anesthesiology, Ankara, Turkey
}

\begin{abstract}
Objective: Due to the recent increase in the successful pregnancies after renal transplant, the number of renal transplant recipients having vaginal or cesarean delivery possibly associated with high maternal, fetal and/or neonatal risk requiring team approach increased. We aimed to evaluate antenatal follow-up, perinatal outcomes, and anesthesia management in pregnancies with renal transplantation and to compare them with the current literature. Materials and Methods: After ethics committee approval, renal transplant recipients who gave birth in our hospital between January 2010 and December 2019 were documented in this retrospective study. Demographic characteristics, comorbidities, antenatal follow-up, anesthesia management, and maternal, fetal, and neonatal outcomes were presented.

Results: A total of 20 pregnant women who underwent renal transplant were identified. The mean age of the parturients was $31 \pm 5$ years. The median interval from transplantation to conception was $8.15 \pm 4.8$ years. Antenatal mean serum creatinine level and proteinuria were $1.48 \pm 1.39 \mathrm{mg} / \mathrm{dL}$ and $1.397 \pm 1.316$ $\mathrm{mg} / \mathrm{dL}$, respectively. No allograft rejection was recorded. Comorbidities including hypertension $(\mathrm{n}=12)$, preeclampsia $(\mathrm{n}=6)$, and preterm delivery $(\mathrm{n}=10)$ were noted. The median gestational age was $35 \pm 3$ weeks and the median newborn weight was $2.520 \pm 832$ gram. There was one abortion, two pregnancy terminations, and 17 deliveries ( 3 vaginal and 14 cesareans). Cesarean sections (11/14; 78.6\%) were mostly performed under spinal block and general anesthesia was performed in three (21.4\%) women. Epidural analgesia for vaginal delivery was recorded in one parturient.

Conclusion: Despite the presence of preterm delivery and comorbidities, antenatal/peripartum follow-up and analgesia/anesthesia management of renal transplant recipients revealed good perinatal outcomes.
\end{abstract}

Keywords: Anesthesia, spinal, general, surgery, cesarean/labor and delivery, renal transplantation

Öz

Amaç: Son zamanlarda böbrek nakli sonrası başarılı gebeliklerin artması nedeniyle, yüksek maternal, fetal ve/veya neonatal risk ile ilişkili olarak ekip yaklaşımı gerektiren vajinal veya sezaryen doğum olan böbrek transplant alıcıları artmıştır. Renal transplantasyonlu gebeliklerde antenatal takibi, perinatal sonuçları ve anestezi yönetimini güncel literatürle karşılaştırmak için değerlendirmeyi amaçladık.

Gereç ve Yöntemler: Etik kurul onayından sonra, Ocak 2010 - Aralık 2019 tarihleri arasında hastanemizde doğum yapan böbrek nakli alıcıları bu retrospektif çalışmada belgelendi. Demografik özellikler, komorbiditeler, antenatal takip, anestezi yönetimi ve maternal, fetal ve neonatal sonuçlar sunuldu. Bulgular: Böbrek nakli yapılan toplam 20 gebe belirlendi. Doğum yapanların ortalama yaşı $31 \pm 5$ yıldı. Transplantasyondan gebe kalmaya kadar geçen

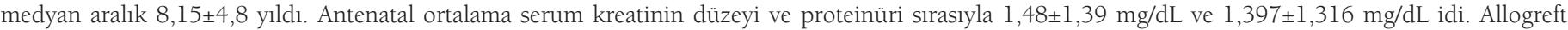
reddi izlenmedi. Hipertansiyon $(n=12)$, preeklampsi $(n=6)$ ve erken doğum $(n=10)$ gibi komorbiditeler izlendi. Ortanca gebelik yaşı $35 \pm 3$ hafta ve ortanca

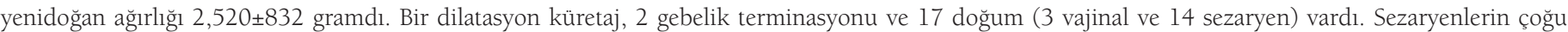
$(11 / 14 ; \% 78,6)$ spinal anestezi altında yapıldı ve üç $(\% 21,4)$ gebeye genel anestezi uygulandı. Doğum eylemi ve vajinal doğum için epidural analjezi 1

PRECIS: In our study, we evaluated antenatal follow-up, perinatal outcomes and anesthesia management in pregnancies with renal transplantation by comparing them with the current literature.

Address for Correspondence/Yazışma Adresi: Ezgi Turgut MD, Gazi University Faculty of Medicine, Department of Obstetrics and Gynecology, Ankara, Turkey Phone: +90 5065262353 E-mail: ezgi_sariakcali@hotmail.com ORCID ID: orcid.org/0000-0002-5509-7888

Received/Geliş Tarihi: 08.03.2021 Accepted/Kabul Tarihi: 12.04.2021

${ }^{\circledR}$ Copyright 2021 by Turkish Society of Obstetrics and Gynecology

Turkish Journal of Obstetrics and Gynecology published by Galenos Publishing House 
gebede uygulandi.

Sonuç: Preterm doğum ve komorbiditelerin varlığına rağmen, renal transplant alıcılarının antenatal/peripartum takibi ve analjezi/anestezi yönetimi iyi perinatal sonuçlar ortaya koydu.

Anahtar Kelimeler: Anestezi, spinal, genel, cerrahi, sezaryen ve doğum, renal transplantasyon

\section{Introduction}

After the first successful pregnancy in a renal transplant recipient in $1958^{(1)}$, a recent meta-analysis including 4,706 pregnancies among 3,570 renal transplant recipients reported a live birth rate of $73.5 \%{ }^{(2)}$. Pregnancy after renal transplantation carries maternal (e.g. allograft rejection, infection, hypertension or preeclampsia), fetal (spontaneous abortion, premature delivery, fetal growth restriction, and intrauterine fetal death) and neonatal (recurrence risk of the underlying maternal kidney disease that might occur in offspring) high risk ${ }^{(3-6)}$. Additionally, the type of anesthesia and/or analgesia and its management may be challenging in these pregnant women due to either preoperative hypovolemia or spinal anesthesia-induced hypotension along with the changed renal physiology during pregnancy, and rarely, the presence of immunosuppressive therapy, which may increase infection risk ${ }^{(7)}$. As the number of renal transplantations and parturients with renal transplant have increased, there is an anticipated high risk in perinatal outcomes because this particular group of patients is under immunosuppression treatment and has several comorbidities. Therefore, we aimed to revisit the risks and characteristics of these recipients by documenting our experience to provide updated national information for comparison with international data.

\section{Materials and Methods}

After obtaining approval from the ethics committee (decision number: 503, dated: 20.07.2020), the database of our institution was searched between January $1^{\text {st }}, 2010$, and December $31^{\text {st }}, 2019$, for renal transplants and pregnancy. We specifically identified post-renal transplant, pregnant patients. Data including maternal age, the time elapsed from renal transplant to delivery, reason for transplantation, maternal comorbidities, gestational age, gravity and parity, and immunosuppressant medication were documented. Antenatal follow-up of renal functions in terms of serum creatinine (SCr) levels and estimated glomerular filtration rate (eGFR) were recorded from the records to elucidate the incidence of allograft rejection. Antenatal or peripartum anesthesia data were the mode of delivery, analgesia or anesthesia provided, anesthesia monitoring used, and complications related to obstetrics or anesthesia. Obstetric outcomes in terms of maternal, fetal and neonatal were noted from the records. Maternal outcomes included the rate of maternal mortality, cesarean section (CS), preeclampsia and/or proteinuria (total urine protein $>0.3 \mathrm{~g} /$ day during pregnancy), hypertension, gestational diabetes mellitus, and anemia (hemoglobin $<10.5 \mathrm{~g} / \mathrm{dL}$ and $<11 \mathrm{~g} / \mathrm{dL}$ in the $2^{\text {nd }}$ and $3^{\text {rd }}$ trimester, respectively). All patients' blood pressures were under control with an antihypertensive agent. Fetal outcomes consisted of spontaneous abortion, stillbirth, preterm birth, intrauterine growth retardation, perinatal death, newborn weight, and Apgar scores (at 1 and 5 minutes).

\section{Statistical Analysis}

Statistical analysis was conducted using the SPSS version 21.0 package. After performing descriptive statistics, data were presented as number (n), rate (\%), mean and standard deviation or median where appropriate. Neonatal data according to maternal eGFR groups were compared using the t-test. The number of patients with three different eGFR intervals was compared using the chi-square test. A p-value $<0.05$ was considered statistically significant.

\section{Results}

The demographic characteristics of parturients (as renal transplant recipients), those who underwent normal spontaneous vaginal deliveries (NSVD) or CS, are presented in Table 1 . The mean maternal age was $31 \pm 5$ years, the rate of nulliparity was $45 \%$, and two patients became pregnant via in vitro fertilization. Renal transplant recipients (two of whom had two deliveries) included three NSVD, 14 cesarean deliveries, two pregnancy terminations, and one abortion. The mean interval from transplantation to conception was $8.15 \pm 4.83$ years. The causes of end-stage renal failure requiring transplant and immunosuppressive regimen of the patients are presented (Table 1).

\section{Antenatal Follow-up}

Antenatal follow-up of renal outcomes is presented in Table 2. The mean $\mathrm{SCr}$ level in the $1^{\text {st }}$ trimester was $1.48 \pm 1.39$ $\mathrm{mg} / \mathrm{dL}$ and the mean $1^{\text {st }}$-trimester eGFR was $78.1 \pm 8.3 \mathrm{~mL}$ $\mathrm{min} / 1.73 \mathrm{~m}^{2}$. After delivery, the mean SCr level and eGFR were $1.42 \pm 0.22 \mathrm{mg} / \mathrm{dL}$ and $64.7 \pm 8 \mathrm{~mL} / \mathrm{min} / 1.73 \mathrm{~m}^{2}$, respectively. These parameters were not different between the $1^{\text {st }}$ trimester and after delivery.

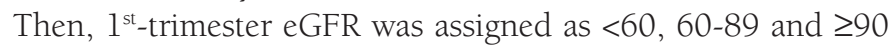
$\mathrm{mL} / \mathrm{min} / 1.73 \mathrm{~m}^{2}$. The number of patients with each eGFR is presented in Table 2. The mean 24-h urine protein was $1,397 \pm 1,316 \mathrm{~g} /$ day; $60 \%$ of them had $>0.3 \mathrm{~g} /$ day proteinuria. No allograft rejection records were observed in any of the recipients, either before or after pregnancy.

\section{Perinatal Outcome}

The obstetric outcomes, maternal comorbidities before pregnancy and peripartum morbidity and mode of delivery, 
Table 1. Demographics and clinical characteristics of the parturients (mean $\pm \mathrm{SD}$, range, $\mathrm{n}$ or \%)

\begin{tabular}{ll} 
Maternal age (years) & $31 \pm 5(19-42)$ \\
\hline Gestational age (week) & $35 \pm 3(28.6-40)$ \\
Gravity & $2.4 \pm 1.9(1-7)$ \\
\hline Parity & $0.6 \pm 0.9(0-3)$ \\
Nulliparity & $9(45 \%)$ \\
IVF & $2(10 \%)$ \\
$\begin{array}{l}\text { Interval between transplantation to delivery } \\
\text { (years) }\end{array}$ & $8.15 \pm 4.83(2-19)$
\end{tabular}

\section{Reason for renal transplantation}

\begin{tabular}{ll} 
Glomerulonephritis & $4(20 \%)$ \\
\hline Hypertension & $4(20 \%)$ \\
\hline Reflux nephropathy & $3(15 \%)$ \\
\hline Unspecified end-stage renal diseases & $5(25 \%)$ \\
\hline Wilms tumor & $1(5 \%)$ \\
\hline Amyloidosis & $1(5 \%)$ \\
\hline DM & $1(5 \%)$ \\
\hline Recurrent UTI & $1(5 \%)$ \\
\hline Immunosuppressive medication & \\
\hline Tacrolimus & $90 \%$ \\
\hline Prednisone & $75 \%$ \\
\hline Azathioprine & $75 \%$ \\
\hline Tacrolimus/azathioprine/prednisolone & $12(60 \%)$ \\
\hline Tacrolimus/azathioprine & $3(15 \%)$ \\
\hline Other combination & $5(25 \%)$ \\
\hline
\end{tabular}

DM: Diabetes mellitus, UTI: Urinary tract infection, IVF: In vitro fertilization, SD: Standard deviation

indications for CS, and type of anesthesia are shown in Table 3. There were 17 singleton live births, 14 of which were CS and three were NSVD. Eleven parturients received single-shot spinal anesthesia using $10 \mathrm{mg}$ of hyperbaric bupivacaine with opioids (fentanyl $10 \mu \mathrm{g}$ and morphine $100 \mu \mathrm{g}$ ). Three patients received general anesthesia. General anesthesia induction was provided using intravenous (IV) $5 \mathrm{mg} / \mathrm{kg}$ of thiopental and 1 $\mathrm{mg} / \mathrm{kg}$ succinylcholine followed by 1 MAC of sevoflurane in $50 \%$ oxygen-air mixture until delivery of the newborn, and then by adding $0.2 \mu \mathrm{g} / \mathrm{kg} / \mathrm{h}$ of IV remifentanil infusion. One of the NSVDs received epidural analgesia using $0.125 \%$ bupivacaine with $2 \mu \mathrm{g} / \mathrm{mL}$ fentanyl.

Peripartum fluid administration was 78\% saline and 21\% Ringer's lactate. The mean perioperative arterial pressure (MAP) ranged between $77 \pm 12$ to $105 \pm 14 \mathrm{~mm}$ Hg. Records revealed that spinal anesthesia-induced hypotension was treated with ephedrine or noradrenaline. Post-dural puncture headache was reported in four out of 14 patients who underwent CS.
Table 2. Renal function tests and outcomes (mean $\pm \mathrm{SD}$, range, $\mathrm{n}$ or \%)

Before delivery- $1^{\text {st }}$ trimester $(n=20)$

$\begin{array}{ll}\text { Creatinine }(\mathrm{mg} / \mathrm{dL}) & 1.48 \pm 1.39(0.6-5.89) \\ \text { eGFR }\left(\mathrm{mL} / \mathrm{min} / 1.73 \mathrm{~m}^{2}\right) & 78.1 \pm 8.3(8.3-136.8) \\ <60 & 6(30 \%) \\ 60-89 & 5(25 \%) \\ >90 & 9(45 \%)\end{array}$

After delivery $(\mathrm{n}=17)$

Creatinine (mg/dL)

$1.42 \pm 0.22(0.6-3.91)$

eGFR (mL/min/1.73 $\left.\mathrm{m}^{2}\right)$

$64.7 \pm 8(13.4-119.3)$

$<60 \quad 8(47 \%)$

$60-89 \quad 4(23 \%)$

$>90 \quad 5(30 \%)$

$24 \mathrm{~h}$ urine protein

$1.397 \pm 1.316(138-4.511)$

$>0.3$ g/day

$12(60 \%)$

$\begin{array}{lc}\text { Allograft rejection during or after pregnancy }(\mathbf{n}=\mathbf{2 0}) \\ \text { Yes } & 0 \\ \text { No } & 20\end{array}$

eGFR: Estimated glomerular filtration rate, SD: Standard deviation

\section{Neonatal Outcome}

The median duration of gestation was $35 \pm 3$ weeks (abortion and terminations were not included). There were 10 (58\%) preterm deliveries. Preterm birth indications were ablatio placenta $(n=2)$, spontaneous preterm birth $(n=3)$, premature rupture of the membranes $(n=2)$, and severe preeclampsia $(n=3)$. The median birth weight was 2,520 \pm 832 grams (10 females and 7 males), with five newborns (29\%) having low birth weight and two newborns (11\%) having very low birth weight. Two newborns (11\%) had Apgar scores $<7$ at 1 minute and 1 newborn (5\%) had an Apgar score $<7$ at 5 minutes. The mean umbilical artery $\mathrm{pH}$ was $7.37 \pm 0.05$.

We assigned our patients into three groups according to their eGFR as <60, 60-90, >90 mL/min/1.73 $\mathrm{m}^{2}$ (Table 4). Then, we compared their perinatal results including gestational week at delivery, birth weight, umbilical artery $\mathrm{pH}$, and Apgar scores. In group eGFR >90 mL/min/1.73 m², we observed higher birth weight, gestational week at delivery, and $1^{\text {st }}$ minute Apgar score, but there were no significant differences between the groups ( $\mathrm{p}=0.580, \mathrm{p}=0.788$, and $\mathrm{p}=0.715$ respectively). The neonatal intensive care unit admission rate was $41.2 \%$; the indications were tachypnea (57.1\%) and low Apgar score (28.6\%).

\section{Discussion}

We have reported antenatal follow-up, and anesthesia and/or analgesia management and perinatal outcomes in parturients with renal transplantation who underwent CS or NSVD. 
Table 3. Renal recipient data, type of delivery and anesthesia (mean $\pm \mathrm{SD}$, range, $\mathrm{n}$ or $\%)$

\section{Comorbidity before pregnancy $(n=20)$}

Hypertension

$4(20 \%)$

Type 2 DM

$1(5 \%)$

Maternal data $(\mathrm{n}=17)$

Preeclampsia

Gestational DM

Anemia $12(70 \%)$

- No treatment (n) 3

-IV Iron (FCM) replacement (n) 2

-Blood product (ES) Use (n)

7

Mode of delivery (n)

CS $14(82.4 \%)$

NSVD

$3(17.6 \%)$

\section{Indication for CS}

Previous CS $7(50 \%)$

Maternal medical indication

$3(21.4 \%)$

Presentation abnormality

$2(14.3 \%)$

Placental abruption

Anesthesia type for CS $(n=14)$

Spinal $(\mathrm{n}=11)$ $11(78.6 \%)$

General $(n=3)$ $3(21.4 \%)$

Epidural Analgesia for NSVD (n)

1

DM: Diabetes mellitus, IV: Intravenous, FMC: Ferric carboxymaltose, ES: Erythrocyte suspension, CS: Cesarean section, NSVD: Normal spontaneous vaginal delivery, SD: Standard deviation

Table 4. Neonatal data according to maternal eGFR (mL/ $\left.\mathrm{min} / 1.73 \mathrm{~m}^{2}\right)($ mean $\pm \mathrm{SD})$

\begin{tabular}{llllll} 
& eGFR $<60$ & eGFR 60-89 & eGFR $\geq 90$ & $p$ \\
\hline Gestation at & $34.2 \pm 3.7$ & $34.68 \pm 4.1$ & $36.67 \pm 1.8$ & 0.788 \\
\hline Delivery (week) & & & & \\
UA pH & $7.3 \pm 0.1$ & $7.4 \pm 0$ & $7.3 \pm 0$ & 0.702 \\
\hline Birth weight & $2.296 \pm 812$ & $1.650 \pm 1421$ & $2.506 \pm 476$ & 0.580 \\
Apgar at 1 min & $7.5 \pm 3$ & $6.5 \pm 3.5$ & $8.2 \pm 0.8$ & 0.715 \\
Apgar at 5 min & $9 \pm 2$ & $8 \pm 1.4$ & $9 \pm 1$ & 0.723
\end{tabular}

UA: Umbilical artery, SD: Standard deviation, Abortion and termination were not included in the average delivery week of gestation

Perinatologists and anesthesiologists need to deal with those patients more frequently because the number of pregnant women who previously underwent renal transplantation has increased ${ }^{(2)}$. According to the report of the American Transplantation Association, pregnancy should occur at least a year after renal transplantation ${ }^{(8)}$ though highest maternal complications and the least favorable birth outcomes were observed in the <2-year interval between renal transplantation and pregnancy ${ }^{(2)}$. In the present study, we audited an average interval of 8 years (from 2 to 19 years) between renal transplantation and pregnancy, which is very much acceptable and reliable. Pregnancies after transplantation are considered as high risk because of the higher incidence of pregnancy complications such as miscarriage, preeclampsia, gestational diabetes, need for CS, and premature birth compared with otherwise healthy pregnant women ${ }^{(5,6)}$. Gill et al. ${ }^{(5)}$ found a rate of $32.7 \%$ of preterm birth among 453 pregnant women who had undergone renal transplantation. Bramham et al. ${ }^{(6)}$ observed preeclampsia at a rate of $30 \%$ but no increased risk of gestational diabetes. The CS rate was 82\% among 105 pregnant women with renal transplantation. Similarly, in our study, we documented gestational diabetes, preeclampsia and miscarriage, in addition to rates of CS and preterm delivery of $82.4 \%$ and $58 \%$, respectively.

National authors have shown that maternal and fetal outcomes of renal transplant recipients were mostly dependent on transplanted kidney function determined by eGFR in the $1^{\text {st }}$ trimester of pregnancy ${ }^{(9)}$. In our study, eGFR $>90 \mathrm{~mL} / \mathrm{min} / 1.73$ $\mathrm{m}^{2}$ were recorded in 9 out of 20 patients in the $1^{\text {st }}$ trimester, whereas it was in 5 out of 17 parturients after delivery.

Immunosuppressive medication including tacrolimus, azathioprine, and low-dose corticosteroids are well tolerated in pregnancy without significant risk in renal transplant recipients ${ }^{(10,11)}$, but mycophenolate mofetil, sirolimus, and mammalian target of rapamycin inhibitors are contraindicated in pregnancy ${ }^{(12)}$. Sixty percent of our patients were using a combination of tacrolimus, azathioprine, and prednisolone, and none of the chemotherapeutics that are contraindicated was documented and used in our audit. Immunosuppressive medication can manifest serious adverse effects or complications, steroids and tacrolimus may cause commonly leukopenia and rarely epidural abscess ${ }^{(13)}$. Currently, no such serious adverse effects or complications have been documented. Regarding the use of neuraxial analgesia and/or anesthesia techniques in renal transplant recipients, obeying a strict aseptic technique is a must as stated ${ }^{(13)}$. Although there is no particular recommendation for prophylactic antibiotic use, it is routinely administered before the skin incision in our obstetric anesthesia practice.

In a retrospective analysis of a multicenter cohort study, 83 renal transplant recipients had vaginal and cesarean delivery with a mean gestation of $36 \pm 0.5$ (range, 25-40) weeks. Then, 44 out of $83(53 \%)$ parturients underwent CS; 33 out of 44 (75\%) of these parturients received neuraxial anesthesia and 11 out of 44 (25\%) underwent general anesthesia. The choice of neuraxial techniques includes single-shot spinal (56.8\%), epidural (13.6\%), and CSE anesthesia $(4.6 \%)^{(7)}$. In our single- 
center retrospective analysis including 17 deliveries (17.6\% and $82.4 \%$ were NSVD and CS, respectively) at $35 \pm 3$ weeks of gestation, neuraxial anesthesia was the most commonly chosen technique for CS (11 out of $14 ; 78.6 \%$ ); the remainder (21.4\%) received general anesthesia. In contrast to the multicenter study including three major tertiary hospitals in Israel ${ }^{(7)}$, our CS rate was very much higher ( $82.4 \%$ vs $53 \%$ ) due to the comorbidities and previous CS indication that required CS. Additionally, single-shot spinal anesthesia was the only technique we chose, accounting for $78.6 \%$, and higher than the $56.8 \%$ rate reported by Ioscovich et al. ${ }^{(7)}$.

According to national data related to pregnancy and renal transplantation, eight pregnancies in eight renal transplant recipients were reported between 1975 to 2003 ( $\approx 28$-year period) and pregnancy had no negative impact on renal function after a 2-year follow-up ${ }^{(14)}$. The mean gestation time in the seven planned pregnancies was $35.5 \pm 3.0$ (range 31.2 to 38) weeks ${ }^{(14)}$.

Herein, 17 pregnant renal transplant recipients delivered successfully with both predelivery and postdelivery good graft function during a 10-year period. Similarly, the present mean gestation time for all these parturients was $35 \pm 3$ (range 28.640) weeks, which was comparable to previous studies ${ }^{(7,14)}$. We documented that single-shot spinal anesthesia was provided with hyperbaric bupivacaine plus opioids. The average intraoperative fluid administration in our study was 1.2-1.3 L of saline and/or lactated Ringer's solution. In this population, adequate volume replacement has been recommended as a prerequisite to maintain placental perfusion and to avoid critical renal hypoperfusion ${ }^{(7)}$. Spinal anesthesia-induced hypotension is a known common complication, and we needed to treat only four patients (the rest were mostly hypertensive) with vasopressors to maintain maternal renal and placental perfusion. We provided a strict aseptic technique during neuraxial anesthesia practice to avoid spinal/epidural abscess or any other infectious complications because these patients are also at high risk because of their ongoing immunosuppressive therapy. In the current retrospective analysis, despite the presence of preterm delivery and comorbidities, antenatal and peripartum follow-up and analgesia/anesthesia management of parturients as renal transplant recipients were uneventful and revealed good perinatal outcomes, consistent with both international and national analyses.

\section{Study Limitations}

Our study has some limitations. First, it has a retrospective design and the second is that it is conducted in a single institution. Studies involving many centers and evaluating more patients will improve our knowledge about kidney transplant patients.

\section{Conclusion}

When we evaluated all these obstetric and neonatal data in our study, we observed that renal transplant patients have been found to have higher obstetric complications like preterm delivery than the normal population. However antenatal/ peripartum follow-up and analgesia/anesthesia management of renal transplant recipients revealed good perinatal outcomes.

\section{Ethics}

Ethics Committee Approval: The local ethics committee approved the study (decision number: 503, dated: 20.07.2020).

Informed Consent: Retrospective study.

Peer-review: Externally and internally peer-reviewed.

\section{Authorship Contributions}

Concept: D.B.G., M.B., E.T., Design: D.B.G., M.B., E.T., Data Collection or Processing: S.K., B.B., Analysis or Interpretation: D.K., G.İ., Literature Search: D.B.G., G.İ., Writing: E.T., D.B.G., G.İ., B.B.

Conflict of Interest: The authors report no conflict of interest. Financial Disclosure: Authors have no financial interests about the research.

\section{References}

1. Murray JE, Reid DE, Harrison JH, Merrill JP. Successful pregnancies after human renal transplantation. N Eng J Med 1963;269:341-3.

2. Deshpande NA, James NT, Kucirka LM, Boyarsky BJ, GaronzikWang JM, Montgomery RA, et al. Pregnancy outcomes in kidney transplant recipients: a systematic review and meta-analysis. Am J Transplant 2011;11:2388-404.

3. Levidiotis V, Chang S, McDonald S. Pregnancy and maternal outcomes among kidney transplant recipients. J Am Soc Nephrol 2009;20:2433-40.

4. Fischer T, Neumayer HH, Fischer R, Barenbrock M, Schobel HP, Lattrell BC, et al. Effect of pregnancy on long-term kidney function in renal transplant recipients treated with cyclosporine and with azathioprine. Am J Transplant 2005;5:2732-9.

5. Gill JS, Zalunardo N, Rose C, Tonelli M. The pregnancy rate and live birth rate in kidney transplant recipients. Am J Transplant 2009;9:1541-9.

6. Bramham K, Nelson-Piercy C, Gao H, Pierce M, Bush N, Spark P, et al. Pregnancy in renal transplant recipients: a UK national cohort study. Clin J Am Soc Nephrol 2013;8:290-8.

7. Ioscovich A, Orbach-Zinger S, Zemzov D, Reuveni A, Eidelman LA, Ginosar Y. Peripartum anesthetic management of renal transplant patients-a multicenter cohort study. J Matern Fetal Neonatal Med 2014;27:484-7.

8. McKay DB, Josephson MA, Armenti VT, August P, Coscia LA, Davis $\mathrm{CL}$, et al. Reproduction and transplantation: report on the AST consensus conference on reproductive issues and transplantation. Am J Transplant 2005;5:1592-9.

9. Madazlı R, Kaymak D, Alpay V, Erenel H, Dincer MT, Seyahi N. Evaluation of obstetric outcomes and prognostic significance of graft function in kidney transplant recipient pregnancies. Hypertens Pregnancy 2020;39:89-94.

10. Hart A, Smith JM, Skeans MA, Stewart DE, Cherikh WS, Wainright JL, et al. Kidney. Am J Transplant 2016;16(Suppl 2):11-46. 
11. Hall M. Chronic renal disease and antenatal care. Best Practice Res Clin Obstet Gynaecol 2019;57:15-32.

12. Sifontis NM, Coscia LA, Constantinescu S, Lavelanet AF, Moritz MJ, Armenti VT. Pregnancy outcomes in solid organ transplant recipients with exposure to mycophenolate mofetil or sirolimus. Transplantation Vol 82. Transplantation 2006;82:1698-702.
13. Grownwald C, Vowinkel T, Hahnenkamp K. Regional anesthetic procedures in immunocompromised patients: risk of infection. Curr Opin Anesth 2011;24:698-704.

14. Başaran O, Emiroğlu R, Seçme S, Moray G, Haberal M. Pregnancy and renal transplantation. Transplant Proc 2004;36:122-24. 